\title{
EFFECTS OF ADRENALECTOMY ON MALE-INDUCED PREGNANCY BLOCK IN MICE
}

\author{
R. L. SNYDER AND N. E. TAGGART \\ The Penrose Research Laboratory, Zoological Society of Philadelphia, \\ and Department of Pathology, School of Medicine, \\ University of Pennsylvania, Philadelphia, Penn., U.S.A.
}

(Received 20th March 1967)

\begin{abstract}
Summary. Adrenalectomized female mice ( $\mathrm{CR}$ albino and a wild strain) were exposed to strange males $24 \mathrm{hr}$ after insemination. Exposure of adrenalectomized GR females had no demonstrable effect while sham-operated GR females had a significant number of pregnancies blocked by this treatment. Wild females were considerably more sensitive to the strange males. Adrenalectomy again acted to protect against pregnancy block but not to the same degree as in the laboratory strain. It was concluded that the pituitary-adrenal axis is involved as part of the endocrine mechanisms blocking pregnancy.
\end{abstract}

\section{INTRODUCTION}

Bruce $(1959,1960 \mathrm{a}, \mathrm{b}, 1961)$ has described a block to implantation in certain strains of mice caused by proximity of strange males. Olfaction is presumed to play an important part in this phenomenon because direct contact is not required and anosmic females are not affected (Bruce \& Parrott, 1960). Moreover, pregnancies are also blocked by exposure of females to urine of males or to androgenized females (Dominic, 1964, 1965). The primary endocrine cause of the block is attributed to failure of luteotrophin secretion (Parkes, 1961; Parkes \& Bruce, 1961; Dominic, 1966).

Subsequent studies have demonstrated that proximity of a strange male and exposure to male urine are not the only stimuli that induce the block to pregnancy. Wild house mice (Mus musculus) are extremely sensitive to the presence of a strange male, but changes in the physical environment, such as disrupting the contents of the cage twice daily, are equally effective in inducing the pregnancy block (Chipman \& Fox, 1966). Changes in cage size alone have been shown to reduce the pregnancy rate in deermice (Peromyscus maniculatus) to the same degree as the strange male (Eleftheriou, Bronson \& Zarrow, 1962). Bronson, Eleftheriou \& Garick (1964) found that pregnancy could be blocked in deermice $(P . m$. bairdii) by exposure to females of a different subspecies (P. m. gracilis).

The fact that changes in the physical environment were capable of blocking pregnancy led us to consider the role of the adrenal glands since these glands in particular are commonly associated with responses to noxious stimuli. Parkes 
(1961) had already suggested that excessive secretion of adrenocorticotrophin (АСTH) was probably not concerned in the reaction because АGTH did not block pregnancies when injected during the critical pre-implantation period. Another reason for supposing that the pituitary-adrenal axis was not involved was that the incidence of the pregnancy block was not augmented by increasing the number of males to which the female was exposed (Bruce, 1963; Bronson \& Eleftheriou, 1963). Thus, it has generally been assumed that the strange male effect was somehow different from the reproductive failures that occur when mice are crowded.

The present experiments explored the role of the adrenal glands in reproductive failures during the pre-implantation period by comparing pregnancy rates of adrenalectomized and intact females when both were exposed to strange males $24 \mathrm{hr}$ after fertilization.

\section{MATERIALS AND TECHNIQUES}

Two strains (Mus musculus) were studied: albino mice from Charles River Breeding Laboratories, Inc. (CR) and brown house mice derived from wild stock. CR mice were purchased at 8 weeks of age and housed one to a cage. Wild mice were weaned at 21 days of age and housed one to a cage. Cages were plastic boxes $(11 \times 7$ in.) and mice were fed a standard laboratory ration. Adrenalectomy was performed by the dorsal route under ether anaesthesia. Adrenalectomies and sham operations were completed within 2 days for each of two series of experiments-one series with CR mice and a second series with wild mice. Following adrenalectomy mice were maintained on $1 \%$ saline. The completeness of the adrenalectomy was checked at post-mortem examination; four mice were omitted from the two series because of incomplete adrenalectomies.

Mice were paired with a stud male of the GR strain and examined each morning for vaginal plugs, which were considered evidence of insemination. Females were treated in either of two ways after insemination: (1) transferred to a cage containing a strange male of the wild strain $24 \mathrm{hr}$ later, or (2) allowed to remain undisturbed with the stud male. Pregnancy was determined by autopsy and examination of the uterus for implantations on the 7th day of pregnancy. Females were randomly assigned for treatment. Experiments I to IV were conducted simultaneously with GR females which were 10 weeks old when first paired. Experiments V and VI with wild females, ranging in age from 2 to 4 months, were begun immediately after the CR experiments were terminated. Controls (VII) for the wild females consisted of unrelated breeding trials which immediately preceded this study. In these trials, virgin wild females ( 2 to 6 months old) were paired with virgin wild males for 14 days. Females were allowed to litter undisturbed but those that had not delivered young after 21 days were killed with ether and examined for placental scars. Either littering or the presence of placental scars was accepted as proof of pregnancy.

\section{RESULTS}

Data on pregnancy rates are contained in Table 1 and the $\chi^{2}$ analysis in Table 2. The pregnancy rate of adrenalectomized CR females was equivalent to that 
of the intact GR females. Exposure of adrenalectomized GR females to strange males had no demonstrable effect while sham-operated GR females had a significant number of pregnancies blocked by this treatment.

Wild females were extremely sensitive to the strange males even though they were not aliens. Adrenalectomy again acted to protect against pregnancy block although not to the same degree as in the CR females.

TABLE 1

PREGNANGY RATES OF MICE SUBJECTED TO VARIOUS TREATMENTS

\begin{tabular}{l|c|c}
\hline \multicolumn{1}{c|}{ Treatment and strain of female } & $\begin{array}{c}\text { No. of } \\
\text { females }\end{array}$ & $\begin{array}{c}\% \\
\text { Pregnant }\end{array}$ \\
\hline I. Intact CR-no exposure & 38 & 89 \\
II. Adrenalectomized CR-no exposure & 41 & 93 \\
III. Adrenalectomized CR-exposed & 35 & 97 \\
IV. Sham-CR-exposed & 36 & 67 \\
V. Adrenalectomized wild-exposed & 37 & 49 \\
VI. Sham wild-exposed & 42 & 17 \\
VII. Intact wild-controls & 110 & 90 \\
\hline
\end{tabular}

TABLE 2

PROBABILITY LEVELS ASSOGIATED WITH DIFFERENGES IN PREGNANGY RATES BETWEEN VARIOUS TREATMENTS

\begin{tabular}{|c|c|c|c|c|c|c|c|}
\hline Treatment & I & II & III & IV & V & VI & VII \\
\hline $\begin{array}{l}\text { I } \\
\text { II } \\
\text { III } \\
\text { IV } \\
\text { V } \\
\text { VI } \\
\text { VII }\end{array}$ & - & N.S. & $\begin{array}{l}\text { N.S. } \\
\text { N.S. } \\
-\end{array}$ & $\begin{array}{c}<0.05 \\
<0.01 \\
<0.005 \\
\quad-\end{array}$ & $\begin{array}{c}- \\
- \\
\overline{-} \\
\text { N.S. } \\
-\end{array}$ & $\begin{array}{c}- \\
- \\
- \\
<0.005 \\
<0.01 \\
-\end{array}$ & $\begin{array}{c}- \\
- \\
- \\
- \\
<0.005 \\
<0.005 \\
-\end{array}$ \\
\hline
\end{tabular}

\section{DISCUSSION}

We concluded from these results that the adrenal glands are part of the endocrine mechanisms which block pregnancy. Apparently this reaction occurs in response to many different kinds of environmental stimuli and contact with a strange male is only one of several social interactions to which the female responds. In view of these results and those demonstrating the sensitivity of wild mice to changes in the physical environment (Chipman \& Fox, 1966; Eleftheriou et al., 1962; Bronson et al., 1964) we concluded that the pregnancy block was a response to generalized environmental stimuli and not specifically a response to the odour of an alien male.

In a general sense, involvement of the adrenal glands could be construed as a stress response. However, in this instance the effects on reproductive function may involve interactions between the pituitary and the adrenal cortex or the pituitary and the adrenal medulla. The action of ACTH on reproductive function is not clear but at least the following possibilities are recognized (Christian, 
1964): (1) direct action of corticoids on the ovaries, (2) inhibition of gonadotrophin secretion by adrenal androgens, (3) direct inhibition of gonadotrophin secretion by ACTH and (4) direct action of ACTH on the reproductive tract. Dornhorst \& Young (1952) and Caldwell (1962) have implicated epinephrine and norepinephrine from the adrenal medulla because of the potentially harmful uterine contractions produced by these hormones and the fact that adrenal demedullated mice had fewer stillbirths than intact controls when both were subjected to chronic stress throughout gestation. Implantation could conceivably be blocked by any one of these mechanisms.

We believe that our data point to excessive secretion of ACTH as the primary initiator of the pregnancy block. Moreover, the results of these experiments suggest that ACTH can act to block implantation in the absence of the adrenal glands if secreted in sufficient quantity. Christian, Lloyd \& Davis (1965) studied the effects of exogenous ACTH on ovaries of mice using the presence or absence of corpora lutea as an index of ACTH action. If the injections began before maturation, more than 0.5 units daily inhibited luteinization completely for up to 82 days in intact wild house mice and 0.5 units daily inhibited luteinization for 10 days. In adrenalectomized immature mice luteinization was prevented in sixteen of eighteen mice for 42 days by 4 units of AGTH a day, but 2 units a day for 60 days failed to do so. Uterine and vaginal responses also indicated that ovarian function was more completely inhibited in intact than in adrenalectomized mice. They concluded from their studies that AGTH was capable of inhibiting luteinization in the absence of the adrenals but that inhibition was more complete when these glands were present.

Christian et al. (1965) also were concerned with the site of action of ACTH. Injections of fresh male mouse pituitary daily returned ovarian and uterine weight to normal and restored follicular maturation and luteinization in intact and adrenalectomized ACTH-treated females. These results indicated that AGTH inhibited ovarian function indirectly through the pituitary or higher centres rather than by acting directly on the ovaries. Prompted by an earlier study by Varon \& Christian (1963) these workers suggested that the augmentation of the ACTH effects by the adrenals was most likely the result of increased adrenal androgen secretion suppressing gonadotrophins.

Our experiments show clearly that sensitivity to the strange male differs in the two strains employed, which we believe can be explained on the basis of inherent differences in responsiveness. Wild mice are clearly more sensitive to changes of environment than most laboratory strains and their levels of ACTH secretion in response to such changes are probably higher. Thus, it is reasonable to expect some pregnancy blocks to occur in adrenalectomized wild mice. The secretion of ACTH could be sufficiently high to inhibit pituitary gonadotrophin secretion directly as in the case of 4 versus 2 units of АCTH in the experiments conducted by Christian et al. (1965).

Our conclusions concerning physiological mechanisms can be summarized as follows: The pituitary-adrenal axis is involved as part of the endocrine mechanism that blocks implantation when mice are subjected to certain environmental stimuli in early pregnancy. ACTH acting directly at the pituitary or higher levels to inhibit secretion of gonadotrophin(s) during the critical 
pre-implantation stage of pregnancy is most likely a part of this mechanism. At high secretory levels of $\mathrm{ACTH}$, inhibition of gonadotrophin may be accomplished in the absence of the adrenals, but at lower levels inhibition of gonadotrophin may require the added action of adrenal androgens. Other mechanisms to explain the augmentatory action of the adrenals, especially the role of medullary hormones, are not ruled out.

\section{ACKNOWLEDGMENTS}

This study was supported by Grants HD-00543 and HE-5690 from the National Institutes of Health, U.S. Public Health Service.

\section{REFERENCES}

Bronson, F. H. \& Eleftheriou, B. E. (1963) Influence of strange males on implantation in the deermouse. Gen. Comp. Endocr. 3, 515.

Bronson, F. H., Eleftheriou, B. E. \& Garick, E. I. (1964) Effects of intra and inter-specific social stimulation on implantation in deermice. 7. Reprod. Fert. 8, 23.

Bruce, H. M. (1959) An exteroceptive block to pregnancy in the mouse. Nature, Lond. 184, 105.

BRUGE, H. M. (1960a) A block to pregnancy in the mouse caused by proximity of strange males. $\mathcal{F}$. Reprod. Fert. 1, 96.

BRUCE, H. M. (1960b) Further observations on pregnancy-block in mice caused by the proximity of strange males. J. Reprod. Fert. 1, 311.

Bruce, H. M. (1961) An olfactory block to pregnancy in mice. I. Characteristics of the block. Proc. IVth int. Congr. Anim. Reprod., The Hague, p. 159.

BRUCE, H. M. (1963) Olfactory block to pregnancy among grouped mice. J. Reprod. Fert. 6, 451.

Bruce, H. M. \& Parrotr, D. M. V. (1960) Role of olfactory sense in pregnancy-block by strange males. Science, N.Y. 131, 1526.

CALDWELL, D. F. (1962) Stillbirths from adrenal demedullated mice subjected to chronic stress throughout gestation. 7. Embryol. exp. Morph. 10, 471.

Chipman, R. K. \& Fox, K. A. (1966) Oestrous synchronization and pregnancy blocking in wild house mice (Mus musculus). F. Reprod. Fert. 12, 233.

Christian, J. J. (1964) Effect of chronic ACTH treatment on maturation of intact female mice. Endocrinology, 74, 669.

Ghristian, J. J., Lloyd, J. A. \& Davis, D. E. (1965) The role of endocrines in the self-regulation of mammalian populations. Recent Progr. Horm. Res. 21, 501.

Dominic, G. J. (1964) Source of the male odour causing pregnancy block in mice. F. Reprod. Fert. 8, 266.

Dominic, C. J. (1965) The origin of the pheromones causing pregnancy block in mice. J. Reprod. Fert. $10,469$.

Dominic, C. J. (1966) Observations on the reproductive pheromones of mice. II. Neuro-endocrine mechanisms involved in the olfactory block to pregnancy. F. Reprod. Fert. 11, 415.

Dornhorst, A. C. \& Young, M. (1952) The action of adrenaline and nor-adrenaline on the placental and foetal circulation in the rabbit and guinea-pig. F. Physiol., Lond. 118, 282.

Eleftheriou, B. E., Bronson, F. H. \& Zarrow, M. X. (1962) Interaction of olfactory and other environmental stimuli on implantation in the deermouse. Science, $\mathcal{N} . Y .137,764$.

Parkes, A. S. (1961) An olfactory block to pregnancy in mice. II. Hormonal factors involved. Proc. IVth int. Congr. Anim. Reprod., The Hague, p. 163.

Parkes, A. S. \& Bruce, H. M. (1961) Olfactory stimuli in mammalian reproduction: odor excites neurohumoral responses affecting oestrus, pseudopregnancy, and pregnancy in the mouse. Science, N.Y. 134, 1049.

Varon, H. H. \& Christian, J. J. (1963) Effects of adrenal androgens on immature female mice. Endocrinology, 72, 210. 